\title{
"The Sun told me I would be restored to life": Native American Near-Death Experiences, Shamanism, and Religious Revitalization Movements
}

\author{
Gregory Shushan, Dip., BA, MA, PhD \\ University of Wales Trinity Saint David
}

\begin{abstract}
Near-death experiences (NDEs) were commonly the basis for Native American afterlife beliefs, as can be seen in numerous ethnohistorical documentary accounts spanning the continent. They played a key role in responding to Christian missionary teachings and in negotiating cultural-political threats from European dominance. According to indigenous testimony, whole religious movements originated in NDEs, some of which rejected Christianity or incorporated elements of it. Although religious revitalization movements such as the Ghost Dance have long been studied from sociological and political approaches, the near-death experiential dimension has been widely ignored despite its centrality to them. In an examination of some 25 cases, I redress this omission by demonstrating that Native American religious revitalization movements-and indeed afterlife beliefs per se - can be fully understood only by taking NDEs into account alongside socio-political factors.
\end{abstract}

KEY WORDS: Native American culture; near-death experience; afterlife beliefs; experiential source hypothesis; religious revitalization movements

Gregory Shushan, PhD, is Honorary Research Fellow in the Religious Experience Research Centre at the University of Wales Trinity Saint David. He has been Research Fellow at the Ian Ramsey Centre for Science and Religion, University of Oxford, and at the Centro Incontri Umani (The Cross Cultural Centre) at Ascona, Switzerland. He has lectured at universities in the UK, Ireland, and Switzerland and has presented his research in seven countries. His degrees in Eastern Mediterranean Archaeology (Dip., Birkbeck College), Egyptian Archaeology (BA, University College London), Research Methods for the Humanities (MA, University College London), and Religious Studies (Ph.D, University of Wales Lampeter) earned him six scholarly awards. The wider research project in which the present article is situated (Shushan, 2016b) was made possible by a generous grant from the Perrott-Warrick Fund, Trinity College Cambridge, with additional support from the Cedar Creek Institute and the Society for Psychical Research. Dr. Shushan also thanks the IANDS Research Fund for assistance with preparing this article. Correspondence regarding this article should be sent to Dr. Shushan at e-mail: g.shushan@uwtsd.ac.uk. 
Near-death experiences (NDEs) were an integral part of Native American afterlife conceptions across the North American continent. Among the more than 60 accounts I recently discovered through an exhaustive survey of primary sources, more than 20 are accompanied by statements that local afterlife beliefs originated in NDEs (Shushan, 2016b). Individuals who had such experiences often returned with knowledge or instructions given to them ostensibly by spirits in the other world, sometimes leading to a change in existing religious belief or practice, including new ritual songs or dances, decreasing funerary offerings to the dead, moral strictures such as ending wife-beating, and accepting or rejecting elements of Christianity or other colonial influence. NDEs were often foundational to religious revitalization movements such as the Ghost Dance, characterized by ritual dances that led to visionary experiences similar to NDEs. Such movements were frequently concerned with rejecting European colonists, restoring traditional indigenous ways of life, and the dead returning from the spirit world. NDEs could thus be a force of opposition to foreign cultural and political domination.

Although these religious movements have been studied in depth from socio-political historical perspectives, their experiential dimensions have largely been ignored. In this article, following a contextualizing introduction, I will (a) explore the varying ways in which different Native American groups interpreted NDEs in relation to Christianity, (b) examine the relationships between NDEs and Native American religious revitalization movements, and (c) redress the scholarly neglect of the experiential dimensions of these movements by demonstrating that they can be fully understood only by taking the foundational NDEs into account alongside socio-political factors.

\section{Returning from Death in Myth, Shamanism, and NDEs}

Native American religious beliefs were first recorded by European explorers beginning in the 16th century and Christian missionaries in the 17th century. Their reports rarely approached anything like modern ethnographic standards, and it was not until the 19th century that a more systematic and objective kind of recording began. In 1875, ethnologist Hubert Howe Bancroft (pp. 511-529) drew upon numerous early primary sources to generalize about afterlife beliefs continentwide. The main recurring themes he identified included post-mortem 
existence in a spiritual body; darkness and light; barriers; obstacles and perils; meeting deceased relatives; encounters with and assistance from deities; afterlife fates being determined by some evaluation of worth, such as social status, mode of death, earthly behavior and morality, and/or proper funerary ritual; an otherworldly realm described as an idealized mirror-image of Earth; intermediate states; reincarnation and/or numerous types of transformations, such as into heavenly bodies; return to the creation or origin point; and feelings of joy and bliss.

Anthropologist Åke Hultkrantz (1953, p. 473) identified the additional themes of the Milky Way as a path for souls to the land of the dead or, alternatively, one path to a heavenly realm and the other to annihilation (Hultkrantz, 1967/1979, p. 133); afterlife realms located in the sky or underground and reached through the horizon; and the maintenance of social status divisions in the land of the dead (Hultkrantz, 1992, pp. 167-168). The other realm was frequently characterized as a place of dancing, music, and happiness, with unlimited supplies of food and drink. The dead possessed various supernatural, even god-like powers such as shape-changing and affecting people on earth. Underworlds could be positive places or, alternatively, could be gloomy and negative with earthly conditions inverted. In such cases, the dead feared living "visitors," such as near-death experiencers (NDErs) and shamans, as if they were ghosts and found them to be offensive smelling. For the dead, time was distorted, and their diet would be unsavory or inedible on earth (Hultkrantz, 1957, pp. 91-92, 107-112, 115). In some tribes with reincarnation beliefs, it was believed that souls had to wait for a new life to be assigned to them. More often, they were given the choice of whether or not to reincarnate and, if they so chose, to which society and even which parents (Hultkrantz, 1953, pp. 421, 477; see also Mills \& Slobodin, 1994).

Bancroft (1875, p. 522) argued that tribes whose members did not believe in an afterlife were rare exceptions and that most claims of disbelief were due to scholarly error. Similarly, Edward Burnett Tylor (1871/1920, p. 21) had argued that reports of human groups who claimed to disbelieve in an afterlife should be regarded with suspicion.

Native American narratives "of living persons who in dreams, trance or coma have journeyed to the other world and succeeded in returning to the living" are "innumerable" (Hultkrantz, 1957, pp. 19, 236-237). Indeed, the majority of ethnohistorical sources relating Native American beliefs consulted in the course of this research yielded at least one such narrative. One of the most common types is the so- 
called "Orpheus Myth," involving a living individual who travels to an afterlife realm in order to retrieve a loved one, such as a spouse, lover, parent, child, sibling, or friend. A taboo, such as on eating, sexual relations, or relating the experience to others, was typically imposed on the individual by a deity or other important person in the spirit world and was then broken. This violation resulted in the deceased being unable to return to earth or "dying" again, that is, returning to the realm of the dead after a period of time back on earth. Hultkrantz (1957, pp. 7, 19, 57-58, 115, 140, 313ff) found approximately 120 examples from 79 widely distributed societies.

A related narrative type involved shamanism. The term "shamanism" is controversial because it generalizes about various types of practices in widely dispersed, unrelated societies (Kehoe, 2000, pp. 4, $37 \mathrm{ff})$. Although it may be technically appropriate to confine the term to the historically related societies of Central Asia and the sub-Arctic rim who use the Evenki word "shaman," the term has become part of a generally understood academic vocabulary and a useful shorthand for indigenous magico-religious ritual healers, diviners, and/or mediums. Around the continent, Native Americans believed that shamans were able to travel to the other world in spirit-form to retrieve the soul of a sick or apparently dead person. Such journeys were achieved by deliberately inducing altered states of consciousness through practices such as smoking, fasting, extended graveside vigils, and continuous, repetitive drumming, dancing, and singing. There are numerous testimonies of personal experiences of both shamans and ordinary individuals that correspond to Orpheus myth themes and share similarities with NDEs.

Nevertheless, neither Orpheus myths nor shamanic narratives should be confused with accounts of ostensibly historical, factual, spontaneous NDEs. Indeed, the greater similarity among Orpheus myths and shamanic narratives versus among the more idiosyncratic NDE accounts helps to distinguish each phenomenon as a discrete narrative type. Although there is fluidity between these categoriesindeed, some narratives that might seem highly mythologized were indigenously regarded as being true-some indigenous peoples made distinctions between NDE narratives and their mythological and shamanic counterparts. Earlier scholars, such as Franz Boas (1896), Cora Du Bois (1939), Irving Hallowell (1940), Åke Hultkrantz (1957), and Leslie Spier (1935), also recognized such distinctions despite structural similarities across the genres and despite the fact that NDEs had yet to be named and codified at the time of their research. (It is also worth noting the abundance of return-from-death and soul-retrieval 
accounts outside these narrative streams, which lack descriptions of the soul's journey [Gayton, 1935, pp. 283ff; Hultkrantz, 1957, pp. 22, 165ff; Thompson, 1946, p. 351]).

Notwithstanding numerous differences in details, the main recurring elements in Native American NDE accounts are leaving the body in spirit form and seeing one's "corpse"; attempting to interact with living people on earth; journeying to another realm via a spirit road; encountering guides, guardians, obstacles, barriers, and perils; transitioning from darkness to light; entering heavenly realms and underworlds that were idealized mirror-images of earth-though sometimes experienced as reversals by visiting spirits; meeting predeceased others; feelings of happiness or the afterlife being positive and beatific; encountering a deity; being instructed or choosing to return, either because it was not yet time to die or for a specific positive purpose such as bringing information about the afterlife to people on earth; feeling reluctant to return; re-entering the body; upon return, experiencing spiritual renewal or transformation with a change in values or purpose, such as a new ritual or new moral teachings; and continuing vivid recall of the experience. Jenny Wade (2003, pp. 101102) also identified most of these elements in her analysis of 11 Native American NDEs dating from the 17th to the early 20 th centuries.

There is nothing to suggest a European origin of these beliefs or accounts of experiences, as evidenced by the early primary sources which make clear that the local people had not yet been exposed to Christianity, by the widespread consistency of indigenous beliefs and afterlife narratives preceding missionary influence, and by the use of archaic, untranslatable terms and references to ancient times found in the narratives (Hultkrantz, 1957, p. 208). Diffusionist claims often rest upon preconceived assumptions about what was and what was not an indigenous belief to begin with. This is repeatedly the case with conceptions of post-mortem reward and punishment (see, for example, Courlander [1971, p. 213], Hultkrantz [1957, p. 283], Tylor [1871/1920, p. 68], and Rasmussen [1932, p. 33]), though such ideas are found in differing forms in even the earliest pre-Christian reports.

\section{NDEs and the Politics of Religious Experience: In Dialogue with Christianity}

Considering the extent of missionary activity and other forms of European colonial interaction over hundreds of years, it is unsurprising that narratives of Native American NDEs were sometimes accom- 
panied by indigenous-Christian dialogue on the subject of an afterlife. In 1634, the Innu (Montagnais) of eastern Quebec and Labrador told French Jesuit missionary Paul Le Jeune that they gained their knowledge about the afterlife from two of their people who been there and returned. On the basis of that evidence, they contended that Le Jeune's statements about heaven and hell were incorrect, for all "go to the same country, at least, ours do" (Kenton, 1927, pp. 111-112; see also Kenton, 1927, pp. 321, 378-379 for Le Jeune's later elaborations on this report). This resistance was despite the fact that the Innu had already been exposed to Christianity by Basque whalers and referred to the sun as "Jesus," according to missionary Gabriel L'Alemant in 1626 (Kenton, 1927, p. 57). Similarly, in a mid-18th century report of Lutheran missionary Niels Egede, a Greenlandic Inuit shaman (angakkut) claimed to have been to heaven where he "talked with God." He described God as being "big and shiny as the sun," and making thunder and wind sounds. Because the angakkut had gained first-hand experience of the other world and of God himself, he was skeptical about Egede's description of heaven on the grounds that it excluded the presence of seals (Jakobsen, 1999, p. 31).

In one NDE account from the Wyandot (or Huron, of southern Ontario), Le Jeune (1640/1898, pp. 199-201; Kenton 1927, p. 389) heard greater acceptance of Christian teachings. A sick man described having traveled to the border of "the most delightful place imaginable" and seeing a recently deceased Frenchman of his acquaintance. Though he wanted to enter this realm, he was turned away because he had not been baptized. When he revived, he told his people about heaven and its baptism prerequisite. Interestingly, because of his own experience he disbelieved a contemporary Algonquin NDE in which a man revived just as he was being buried and claimed to have been to the land of the dead, which was located at the setting sun. Unlike the Wyandot man, he saw only indigenous people-no Frenchmen. When he returned to his body he claimed he had the power to stay alive but preferred to return to the other world, and so "he lay down and died again." Such NDEs appear to have gained more traction, for when preaching Christian afterlife beliefs to the locals, Le Jeune was told to go ahead and go to the realm he was so certain of because "each loves his own people; for my part, I shall go and find mine" (Hultkrantz, 1980, p. 167).

Additional accounts from the Eastern Woodlands by other 17th century French missionaries also reveal negative attitudes toward Christianity. François le Mercier (1638/1897, p. 51) related the experience 
of an Arendahronon Wyandot man who allegedly died and went to another world. There he met two English women "who warned him that he should not yet go into the land of souls" and that when he returned to life he should burn his robe in order to cure an infectious disease. They further warned him that the French missionaries would carry out genocide against the native peoples. Paul Ragueneau (1646/1897, pp. 25ff) also mentioned Algonquins who had traveled to the land of souls and returned, then described how the dead had renewed bodies and lived a blissful existence in populous cities. The experience led the local people to conclude that the Christian heaven and hell were "fables."

French explorer Nicolas Perrot was the first European visitor to several Algonquin tribes and spent most of his life among them (Blair, 1911 , pp. I, 13-15). Sometime in the late 17 th or early 18 th century, he was told by people of the Great Lakes and Mississippi Valley region that their knowledge of the afterlife came from ancestors who had chanced upon the other realm while on a military expedition. When discovered by the dead, they were escorted back to the border between worlds and told not to return until they died. Though war and death are inextricably linked, there was no overt reference to an NDE. Nevertheless, the claim of an experiential basis for afterlife beliefs is significant, as are the thematic NDE elements of border crossings, other realms, encountering spirits of the dead, and being instructed to return. The experience was said to be directly responsible for the belief that the Algonquin afterlife realm was different from that of Europeans, featuring elements such as crossing an unsteady log over rapids, a danger of drowning, a mountain blocking the path to the other world, and two giant pestles that threatened to crush the traveler (Blair, 1911, pp. 89-92).

Latvian missionary Henry George Loskiel (1789/1794, pp. 34-35) wrote that the afterlife beliefs of the Iroquois, also of the Northeastern Woodlands, were based on "the testimony of two Indians, who were dead for several days." Upon revival, they described having traveled "south of heaven" along the Milky Way "to a most glorious city, the inhabitants of which enjoyed every possible good in great abundance." There were separate roads to the other world for Europeans and indigenous people, though the former had blocked the way for the latter, forcing them to make a long detour.

Around 1858, a Makah (Pacific Northwest) man named Harshlah died of an illness. He awoke in his grave but managed to free himself and recounted how he had traveled to the underworld and had seen 
friends and relatives living an enjoyable life. They had no bones, only the skin and flesh that had rotted from their corpses on earth. They told Harshlah that he smelled bad and that he must return to earth. These elements of his experience validated "their ancient ideas," which made it impossible for missionaries "to teach them our views of a future state." The Makah concluded that the white people's afterlife was in heaven and that theirs was in the center of the earth (Swan, 1869, pp. 62-64, 83-84).

During a prolonged illness around 1890, an Eastern Shoshone (Great Basin) man named Enga-gwacu (Red-shirt) Jim had a vision in which the sun told him he was going to die but that he could return to life if he wished. His soul was 10 inches tall and left his body through his thigh. When he looked back at his body he saw that it was still breathing, but after three paces it "dropped, cold and dead." Something suddenly "came down and went clean through my soul." $\mathrm{He}$ descended and found himself in "another world" where he encountered a helper of A'po- - "the Father," described as "a handsome Indian""making some dead men over again." A'po told Enga-gwacu Jim, "You don't look very ill," then withdrew a "thin wire" from a leather bag and tapped it three times. "Then the whole world opened up and I could see the earth plainly. I saw everything there. I saw my own body lying there dead. The Sun told me I would be restored to life" (Lowie, 1909, pp. 301-302). Following his experience, Enga-gwacu Jim "questioned Shoshone medicine-men concerning a hereafter; but mistrust[ed] both their statements and those of the missionaries, because they fail[ed] to tally with his personal experiences" (Lowie, 1909, p. 229).

In the late 19th century, a Sitka (Alaska) Tlingit man died then returned in order to tell his people that the dead require more offerings "and that all who adhered to the traditions of their fathers were the favored ones in the next life ... while those who follow the new Christ-religion were their slaves and sat back in the dark, cold corners" (Knapp \& Childe, 1896, pp. 157-158, 160).

Near death from pneumonia in a U.S. government boarding school hospital in 1907, 17-year-old Hopi (Arizona) youth Don Talayesva (1942, pp. 120-129, 134) was visited by a Guardian Spirit who told him, "You shall travel to the House of the Dead and learn that life is important. The path is already made for you. You had better hurry; and perhaps you will get back before they bury your body." The wind carried his spirit to a mountain, then through a dimly lit tunnel that led to his own village on earth where the only one of his people who could see him was his recently deceased grandmother. He met "a spirit 
god ... directing good people over the smooth highway and bad people over the rough road to the House of the Dead." Talayesva followed the smooth road and rose to the top of a mesa where flowers were blooming and birds were singing, despite the season being midwinter. Black and white striped clowns told him, "you must hurry back to your body," but he proceeded to ancient cliff dwellings of the ancestors where he was criticized for not believing in the land of the dead. To learn "a lesson on life," he had to choose between two pots of suds from which to be washed: one red and one white. Talayesva chose the white one, which ensured he would be able to return to his body. He was then shown a fire pit into which murderers were being pushed by their victims before becoming beetles.

As Talayesva was being escorted back to life, Maasaw (Skeleton Man) came after him wielding a club. Talayesva jumped off a cliff and landed on a clown who told him,

... you have learned your lesson. Be careful, wise, and good, and treat everybody fairly. . . . Go back to the hospital and to your bed. You will see an ugly person lying there [i.e., his own body]; but don't be afraid. Put your arms around his neck and warm yourself, and you'll soon come to life. But hurry, before the people put your body in a coffin and nail down the lid, for then it will be too late.

When Talayesva did as instructed, he found that the hospital staff had prepared his body for burial. His Guardian Spirit appeared again and told him that he would become "an important man in the ceremonies." A chief (Tewaquaptewa) visited Talayesva in the hospital and proclaimed his "death journey . . . was true, for those were the same things that the old people said they saw when they visited the House of the Dead." Talayesva's NDE, recounted at length and in extraordinary detail in his autobiography, led directly to his spiritual renewal in which he rejected 10 years of Christianization and embraced Hopi traditions and beliefs. A similar episode involving red and white pots of suds is reported in a 1930s NDE of an Oraibi Hopi women called Ruth (Titiev, 1972, p. 104), demonstrating that it was-or became, after Talayesva's narrative-a Hopi afterlife narrative theme.

Mormon missionary and interpreter Dimick Huntington (1919, pp. 317-318) reported the NDE of a Ute (Great Basin) warrior named Wah-ker, or Wakara. Around 1840, he "died and his spirit went to heaven." He met "the Lord sitting upon a throne dressed in white," and though he wanted to stay, "the Lord told him that he must return 
to earth." He gave Wah-ker a new name and prophetic information about the coming of the white people "who would be his friends, and he must treat them kindly." Wah-ker converted to Mormonism at one stage, though he alternated between respect for and hostility toward whites.

Although two of the examples here supported Christian doctrine, it was more often the case that NDEs were enlisted as oppositional to missionary teachings. In all cases, however, such accounts demonstrate that NDEs were seen as authoritative sources of beliefs about the afterlife, leading to individuals rejecting particular indigenous and Christian teachings in favor of what they had learned during their own experiences.

\section{NDEs and Religious Revitalization Movements}

A partly distressing NDE reported by Ragueneau (1646/1897, pp. 2933) led to perhaps the first Native American politico-religious revitalization movement. A converted Wyandot woman rose from her burial in a Christian cemetery and recounted her experiences in the heaven of the French, which she described as a realm of fire where Christians burned souls in order to possess them. She was greeted "with firebrands and burning torches, with cruelties and torments inconceivable." Though she was dead only one day, it seemed like years. She was finally assisted by "a certain person, moved with compassion for her," who freed her from her chains and showed her a valley that led to the afterlife realm of indigenous people who had not converted to Christianity. It was a place of delights and goodness, without evil, where people danced and feasted in villages and fields. Because the woman wanted to warn her people of the dangers of converting to Christianity, she decided to "return into her body." The news of her experience "soon spread everywhere" and became "an article of faith" among indigenous people. Additional new beliefs stemming from the experience included that the sky is a fiery realm because it is located close to the sun. The beliefs were still current when Jean de Quen (1657/1897, pp. 289-291) reported that his fellow missionaries were often accused of luring native souls to heaven in order to burn them. Locals cited further individuals "who say that they have risen from the dead and have witnessed all that." One was a "poor Pagan woman" who had apparently died and returned to tell of a similar experience. Whereas such narratives were quite possibly based on Ragueneau's original, de Quen noted the difficulty of convincing the 
people that they were untrue, for they "allege their own experience in confirmation" of their beliefs-including that conversion to Christianity brought postmortem suffering.

In 1680, Tewa religious leader Popé of Ohkay Owingeh pueblo (New Mexico) journeyed to "the magic lagoon of Shipapu, whence his people traced their origin and to which the souls of the dead returned after leaving this life." The ancestors there endowed Popé with supernatural powers and instructed him to return to earth to lead his people in revolt against the Spanish. Back on earth they appeared to him "as shapes of fire" and helped coordinate the Pueblo Revolt (Mooney, 1896, p. 659). That Popé's experience inspired a reassertion and revitalization of indigenous culture reinforces the fact that traditional foundational contexts for cultural and religious innovations often revolved around claims of religious experiences-particularly those brought about by visiting the realm of the dead and returning with new power and knowledge.

In 1762, the Lenape (Delaware) prophet Neolin sought an encounter with the creator deity, the Master of Life. Following prolonged "fasting, dreaming and magical incantations," he set off on his "journey to the spirit world." After eight days he reached a brook at the edge of a meadow and three paths through a forest. The first two were blocked by the "wonderful phenomena" of a "bright flame" leaping from the ground. He followed the third path to "a vast mountain, of dazzling whiteness." A beautiful woman told him that if wished to proceed he must rid himself of his guns, ammunition, supplies, and clothing, and then wash himself in the stream. He obeyed and ascended, and at the summit he found a "rich and beautiful plain" with three fine villages in the distance. A "gorgeously attired" man appeared, welcomed him to the "celestial abode," and took him to the Master of Life who was surrounded by "unspeakable splendour." He told Neolin that the indigenous people must fight the British and cease using European weapons, tools, food, and alcohol. Further, they were to adopt monogamy, cease sorcerous practices, and return to traditional ways of life. Neolin was given a stick carved with a prayer summarizing the new teachings, which he carried back to earth with him as evidence of his experience (Parkman, 1870, pp. 205-207).

A map he drew of the afterlife regions showed separate paths for Europeans and indigenous people, with perils such as an "evil spirit" who would take the dead to hellish realms and enslave them as hunting dogs or horses (Mooney, 1896, p. 667). Neolin's vision was clearly a culturally situated one, brought on deliberately by shamanic ritual, 
rooted in political-historical circumstances, and containing evidently Christian-influenced puritanical elements. Nevertheless, the religious and anti-colonial changes he espoused were grounded in the authority of the experience, which itself was validated and legitimized by the long tradition of shamanic visionary and Orpheus-type narratives and by previous NDE accounts.

In 1805, Shawnee (Ohio Valley) prophet Tenskwatawa appeared to die suddenly, but he revived at his own funeral and claimed that two young men had shown him the spirit world. Though he could look from the border, he was not permitted to enter. Like Neolin, he was given instructions to abandon white ways of life, reassert traditional culture, and impose new moral strictures. Tenskwatawa also claimed to have received revelations from the Master of Life and to be an incarnation of the culture hero/deity Manabozho who was punishing the Natives for abandoning their "purity of life." If they returned to Native ways, Manabozho would reward them with plentiful game and the return of deceased loved ones. Tenskwatawa's testimony had a profound effect on various tribes, leading to over-zealous bans on alcohol and sorcery that sometimes resulted in witch-hunts and immolations. Tenskwatawa's power and authority were sustained by his subsequent regular dreams and visions (Mooney, 1896, pp. 672-674).

Around 1860, the Wanapum (Washington state) prophet Smohalla was apparently killed during a fight with a rival shaman. He revived and described how he had been "in the spirit world and had now returned by divine command to guide his people." Having witnessed his death and return, the people believed his claims and accepted his teachings on the authority of his experience. Smohalla's message was consistent with other revitalization movements, prophesying the disappearance of white colonists, a rejection of their influence, and a return to traditional ways of life. His new "Dreamer" religion (Washani) also combined local belief and ritual with elements of Catholicism and perhaps Mormonism, though Smohalla himself claimed unfamiliarity with Christianity (Ruby \& White, 1989, p. 37). Washani spread to many neighboring tribes, introducing new dances and ceremonies. The religion was sustained partly by further experiences in which Smohalla apparently died, left his body, went to the spirit world, and returned with additional revelations and partly by the trance-visions of his followers via repetitive ceremonial singing and drumming (Mooney, 1896, pp. 718-719, 723, 726-728).

In 1872 at the age of nine, the Oglala Lakota Sioux (Great Plains) shaman Black Elk had an NDE in which he left his body, saw his 
own corpse, traveled to other realms including a transcendent place of bright light, met deceased ancestors, had prophetic visions, re-entered his body, and benefitted from positive fruits of the experience. These thematic elements were combined with highly detailed, clearly cultural elements-such as human-animal/plant transformations; sacred sticks; acquired powers; and local dress, places, and shelters-as well as individual, idiosyncratic elements including multiple ascents, a man of fire in the center of the earth, flaming rainbows, drinking a small blue man in a cup, and a horse's life review. Some features corresponded to existing Ghost Dance teachings and practices, such as a sacred tree, dancing in a circle, themes of vanquishing whites and re-establishing traditional culture and ways of life, and the return of the dead. As such, Black Elk's account served to legitimize his authority and enable him to become a famous, powerful Ghost Dance leader (DeMallie, 1984, p. 259; cf. Wade, 2003, pp. 99-100). Seeking spiritual experiences through "vision quests" was integral to Lakota tradition and "invested a man with a supernatural aura" and "special knowledge and power" (Wade, 2003, pp. 83-84). Significantly, Black Elk's accounts of his deliberately sought Ghost Dance visions were very much like his ostensibly spontaneous NDE, including the attainment of divine knowledge and instructions to take it back to Earth. In one vision he was met by two men who told him it was not yet his time to meet his Father and showed him a Ghost Dance shirt to reproduce on Earth for his people (Wade, 2003, pp. 261-262). In another, a syncretistic Native-Christ figure radiating light instructed him to preach to his people that "earthly things that grow" belong to him, as decreed by his Father. He was taught a new song by 12 women, and 12 men gave him ceremonial sticks to take back with him (Wade, 2003, p. 266). Black Elk himself emphasized that his experiences were not dreams but that they "actually happened" (Wade, 2003, p. 109).

Around 1889, a Northern Paiute (or Paviotso, of the Great Basin) prophet Wovoka (Jack Wilson) lost consciousness during an illness and was taken to the spirit world where he saw deceased ancestors "happy and forever young" in an idealized mirror-image of earth. God told him he must return to his people to preach a message of love, universal peace, and hard work and of no fighting, lying, or stealing. As a reward they would attain a positive afterlife among their friends, one without illness or death. Wovoka became a religious leader who taught a Christian-influenced prophecy of eschatological regeneration: Jesus in cloud-form would bring the dead back to life, ushering in a new golden age, and the dead should therefore not be mourned. The 
dead would also assist in the struggle against white dominance and help drive the colonists away. The Ghost Dance Wovoka brought back from the other world would fulfill this prophecy sooner and help devotees glimpse the future state in dreams (Mooney, 1896, pp. 701-702, $772-774,778,781)$. The religion, with local variation, spread far and wide across the continent to tens of thousands of people in more than 30 tribes, even uniting previously warring peoples. It was maintained through experiential validation in dream cults and through deliberately sought trance-visions of the dead via prolonged dancing (Mooney, 1896, pp. 784ff, 926-927). Du Bois (1939) cited innumerable examples of dances, dream cults, and anomalous healings that maintainedand in some cases outlived - the main Ghost Dance movement.

In 1881, a Squaxin Salish (Washington state) man named Squsacht-un (John Slocum) was confirmed dead by "all present." He later related how he had encountered "a shining light— great light—-trying my soul" and saw his own dead body. He revived temporarily but "died" again, and his soul "went up to the judgment place of God" where he experienced "a great light in my soul from that good land." He was shown a photograph of himself that somehow recorded "all the bad deeds of his life." People he recognized were being burned in a furnace, and Squ-sacht-un learned "all Christ wants us to do," realizing that before his NDE he had been a "sinner." He was given the choice of going to hell or returning to earth to preach the Christian life. An angel told him, "You must go back and turn alive again on earth," and he was shown "a bright land of beauty and comfort, and experienced a sense of deep tranquility" before returning to his body. After reviving he told his people, "Good thing in heaven. God is kind to us. If you all try hard and help me we will be better men on earth" (Mooney, 1896, p. 752 ; Ruby \& Brown, 1996, p. 4).

Squ-sacht-un's subsequent teachings combined Christianity with indigenous elements and a strong experiential character. Followers of the resulting Shaker religion "dreamed dreams, saw visions ... and were taken with a kind of shaking" of their arms and heads, sometimes uncontrollably, while in a "hypnotic condition." The Shakers distinguished themselves from Ghost Dance and Dreamer religions and considered themselves Christians. However, the Bible was not valued

as a book of revelation. They do not need it, for John Slocum personally came back from a conference with the angels at the gates of heaven, and has imparted to them the actual facts and the angelic words of the means of salvation. . . . They know there is a heaven, for John Slocum was there, and believe in a hell of fire for the punishment 
of sinners, because the angels in heaven told John Slocum about it (Mooney, 1896, p. 755).

His authority was also considered superior to that of the Christian Bible because Squ-sacht-un was Native, he was living 1,800 years more recent than Jesus, and he was able to give his testimony in person and in the local language. A statement by Louis Yowaluch, the Church's head in 1893, confirmed that Squ-sacht-un's experience was directly responsible for the foundation of the religion, that faith often lies in the authority of experience, and that the experience claim was not regarded locally as being part of preexisting indigenous tradition:

We heard there was a God from John Slocum-we could see it. Same time we heard God, we believe it. . . . John Slocum came alive, and I remember God and felt frightened. We never heard such a thing as a man dying and bring word that there was a God (Mooney, 1896, pp. 752-755).

Unusual for modern historians, Robert Ruby and John Brown (1996, pp. 9, 34) also saw the experience in such terms, concluding that "this one event in John Slocum's life gave rise to the Indian Shaker Church," and "most important for his credibility was his near-death experience." Jay Miller (1988, p. 194) summarized, "By dying and reviving, John gave personal expression to the concern of the Christian god for Indians, as ancient shamans had died and returned to announce other religious reforms."

Other movements were even more accepting of Christian teachings. Concerning the origins of Iroquois syncretistic indigenous religious movements, Loskiel (1794, pp. 34-35) described certain "preachers"that is, shamans or healers-who "pretended to have received revelations from above, to have travelled into heaven, and conversed with God." Though their descriptions of the journey differed, all said it was perilous, particularly in avoiding being ambushed by "the Devil." Those who passed successfully met "the Son of God," then proceeded "to God himself" who commanded them "to instruct the Indians in the way to heaven," God, and the Devil. Some journeyers, however, only reached the entrance to the other world where they saw smoking chimneys and heard cocks crowing.

Sometime between 1805 and the 1830s, a Wet'suwet'en Dakelh (or Carrier, of British Columbia) prophet named Bini wandered off during a serious illness. His "cold and half desiccated" corpse was discovered months later in nearby woods (Barbeau, 1923, pp. 19ff). During his funeral, he came to life, signing. He could no longer speak 
Wet'suwet'en but could speak only the language of the Sky-beings; however, he magically enabled a youth to understand and interpret for him. He described how his "mind embraced the whole world" when he died. A voice had called him, and he spiritually ascended a ladder that appeared from above: "It was only my shade that was climbing, for my body was left behind." He "pierced the sky vault slowly" as if being born into it, and he saw "the four corners of Heaven." To the west was "a very old man, as tall as a tree, as white as snow," and many white people were sitting motionless. To the east were spirits dressed in white, dancing, drumming, and singing.

After relating the experience, Bini died but returned again to life. This time he told of "the two head-chiefs of the Sky, the Father and the Son." The Son, Zazeekry ("Jesus Christ" in corrupted French pronunciation [Lanoue, 1993, p. 7]), told him of an impending plague and apocalypse brought about by the sins and traditional customs of his people and by their ignorance of Christianity. Bini was baptized and instructed to baptize his people and preach to them repentance and the sign of the cross. A week later he died and returned yet again, this time preaching Christian strictures and displaying items brought back from Heaven: a prayer calendar, a cross, and a white cloth with curative properties. He also had new supernatural powers, including telepathy, precognitive dreaming, and causing dead twigs to blossom (Barbeau, 1923, pp. 38-40).

It was claimed that Bini's experiences occurred prior to missionary influence or "even the appearance of the earliest white men" in the region. Bini allegedly prophesied their arrival, their animals, and their technology and that "they will make life easy for us." Regardless of whether Bini did have prior knowledge of whites, whether the narrative was elaborated over time to lend it more credence, or indeed whether he had genuine clairvoyance, his experiences led to new religious beliefs for himself, his people, and other tribes. His system "became the law of the country," combining indigenous traditions with Christianity together with the new experiential element of the Prophet Dance that participants hoped would enable them to ascend to heaven. Bini's experiences also led directly to a change in afterlife conceptions: "Instead of the Cave-of-the-Dead our home shall be the Sky where the white spirits sing and dance near the gate of sunrise" (Barbeau, 1923, pp. 33, 42, 48-49, 57).

Around 1870, nearly 20 years before Wovoka's NDE, another Northern Paiute prophet named Winawitu visited "the spirit land in a fourhour trance and had seen spirits generally enjoying themselves." 
He returned with newfound clairvoyant and prophetic powers and preached "rejuvenation by dancing" and peace with the whites (Du Bois, 1939, p. 3). Around 1872, a young Sylix (Pacific Northwest) man named Qwelasken died of an illness and returned to life five days later. He claimed that in the other realm he met God who warned him of the end of the world. Qwelasken correctly predicted an earthquake, preached Christianity, and continued to have revelatory dreams of God (Cline, 1930, pp. 172-173).

Also in the 1870s, a Hill Patwin (northern California) prophet named Lame Bill fainted while hunting and fell into a trance state for four days. When he returned to normal consciousness, he told his people about spirits of the dead living in heaven and taught them a new dance he had learned from the spirits. This was the foundation of Bole-Maru, the Dreamer Religion. Prior to his experience, Lame Bill did not believe in his dreams, and his people did not believe in an afterlife: "It was the first time these people had heard such things. He was the first man who saw all this." People were initially skeptical until "they started dreaming themselves." The movement instituted religious and ritual changes to symbolism, feasts, dances, songs, regalia, and funerary practices. Although drawing upon elements of Christianity and preaching strict moral codes, the Bole-Maru was rooted in existing local beliefs in the abilities of shamans to communicate with the dead and in healing through soul retrieval (Du Bois, 1939, pp. 67-69, 137).

\section{Analysis and Conclusions: The Religio-Political Authority of NDEs}

As the above accounts illustrate, such was the authority of NDEs that they often took precedence over new and existing religious teachings when it came to knowledge about the afterlife. Individuals regularly privileged the evidence of their own experiences over the statements of missionaries, and as such the narratives of the experiences became sources of political resistance and cultural-religious empowerment. Near-death and shamanic experiences were particularly crucial to Native American religio-political revitalization movements of the 17th-19th centuries. These cases provide rare glimpses into the process of the formation of new religious beliefs and practices.

In a few cases, new religions formed following extraordinary experiences other than NDEs. The Seneca (Lake Ontario) prophet Sg- 
anyadiyo (Handsome Lake) had a deathbed vision involving visits from supernatural beings and instructions from the creator god to teach his people a new set of strictures. The experience led him to found the Gaihwi:io ("Longhouse Religion"; Parker, 1913, pp. 11, 24). Other examples feature wondrous journeys that may or may not have been in afterlife realms. The Tsuu T'ina (Alberta) head medicine man Calf-Child (Hector Crawler) described a dream-like experience of ascending bodily to a mountain where he met the Son of God, radiating light (Barbeau, 1923, pp. 113-114). A Nakota (Great Plains) boy had a dream-vision in which the Great Spirit Wakantanga instructed him to preach a return to traditional religion and to become a healer (Jenness, 1938, p. 74). Other examples lack contextual details altogether; for example, Kickapoo (Great Plains) prophet Kennekuk had direct revelations from the Great Spirit that led to religious changes (Mooney, 1896, pp. 695ff), and Apache (Arizona) prophet Nakai-Doklini could reportedly communicate with spirits and resurrect the dead (Mooney, 1896, pp. 704-705).

Nevertheless, despite such exceptions, the individuals who founded new religions or brought back new teachings often "gained their positions as Prophets by trance-induced otherworldly experiences" and by virtue of the belief that they had "died, gone to heaven, and returned" with divine wisdom and instructions (Ruby \& Brown, 1989, pp. 13, 30; cf. Kroeber, 1904, p. 32; Mooney, 1896, pp. 922-924). It is significant that the major movements reviewed in Du Bois's (1939) exhaustive survey primarily had NDE foundational contexts, whereas the lesser movements were more often grounded in dreams and visions. Spier (1935) cited many additional examples of such movements together with founding myths that almost invariably involved journeys to the spirit land. That NDEs held greater evidential force is unsurprising considering that unlike these other phenomena, they are rare, spontaneous and unexpected, outwardly dramatic and emotionally charged at the community level, and difficult to convincingly fake. Furthermore, the teachings of cultural-political renewal and promises of resurrection or a heavenly future life were conceptually relevant and consistent with NDEs, sharing the general themes of rebirth and revitalization.

Considering their cultural contexts, it is unsurprising that many of these foundational NDE narratives have a distinctly shamanic character (for example, that of Black Elk; cf. Wade, 2003, p. 112). Although the founders of the religious movements grounded their teachings in 
the authority of ostensible afterlife experiences, the experiences themselves were interpreted through the lenses of local shamanic traditions. To varying degrees, then, the experiences conformed to cultural expectations, including preexisting beliefs, Orpheus myths, and prior shamanic and NDE narratives, whereas the movements themselves were clearly rooted in indigenous traditions. As one Paiute informant stated, Ghost Dance leaders "didn't start anything new. They just learned from the old people" (Du Bois, 1939, p. 4). As outgrowths of existing dreamer-prophet/shamanic-visionary traditions, some of the experiential narratives show signs of borrowing or intertextuality, and indeed some were apparently wholly invented or plagiarized for personal gain. Skolaskin, for example, exploited his status to fulfill his self-professed divine vision of marrying six virgins (Ruby \& Brown, 1989, p. 136) and later admitted that "the whole scheme had been a hoax to gain power" (Ray, 1936, p. 75). Tenskwatawa's account and teachings may well have been based on Neolin's. Nevertheless, given the consistency between these foundational accounts and NDEs cross-culturally, it is both unlikely and groundless to assume that they were all due to such invention. Indeed, no geographical or historical lineage can be drawn to account for any hypothetical widespread transmission.

Although most shamans and prophets achieved their statuses as a result of their experiences, a few already held positions of spiritual leadership. Some had a history of extraordinary experiences, and leaders of these movements were chosen for their trance-journey abilities. Smohalla, for example, had undergone a traditional spirit quest among other extraordinary experiences prior to his NDE (Ruby \& Brown, 1989, p. 20). James Mooney (1896, p. 774) believed that Wovoka's "frequent trances would indicate that, like so many other religious ecstatics, he is subject to cataleptic attacks." Black Elk was also susceptible to such experiences, leading Wade (2003, p. 112) to suggest that he may have been "predisposed . . . to have unique NDEs with richer and more varied content than most." This conclusion is consistent with James McClenon's $(2002,2006)$ theories that shamans and prophets have a higher degree of hypnotizability.

Recognizing the experiential contexts of these religious movements is not to deny the socio-political factors involved or the importance of such factors in asserting cultural identities. The movements certainly reflected anxieties about European dominance and carried messages of either resistance or greater integration. They served community- 
binding functions and constituted efforts at cultural, and indeed physical survival against the threat of annihilation. Christian elements, such as baptism, ideas of salvation, the abandonment of indigenous practices, moral precepts, and acceptance of Jesus, were incorporated to appeal to Christianized locals, to seem less threatening to the Europeans, perhaps in some cases to simply capitulate, and/or to reflect genuine religious feeling. However, whereas the socio-political dimensions of these movements have been amply covered in the scholarly literature (see, for example, Andersson, 2008; Smoak, 2006), the importance of the experiential element has been widely ignored, resulting in an implicit denial of indigenous voices. Although there seems to be an assumption that the narratives were invented for political purposes, this implication is rarely if ever overtly stated. It is not that NDEs are being "explained away" or even doubted; there is simply a general lack of any attempt to interpret or engage with them at all. With few exceptions (for example, Mooney, Hallowell, Hultkrantz, Ruby \& Brown), most discussions of these religious revitalization movements contain at best a brief description of the context and content of the associated experience before focusing strictly on a socio-political analysis of the movement itself.

Arguably, without the experiences these movements would not have come into being - and almost certainly not without the claim of the experience. By ignoring the experiences, the very elements of these religious movements that are the most significant to the members of the societies themselves has been systematically disregarded by most scholars in favor of exclusively Western functionalist explanations, as if the statements of the very people whose beliefs they are supposed to be interpreting are irrelevant. The result is that much of the meaning and significance these movements and experiences had to the people themselves has been sidelined.

Emphasizing the experiential dimension and restoring it to its proper status is not intended as a competing hypothesis but as a supplementary and corrective one. The fact that the experiences occurred in particular historical contexts and were utilized to certain socio-religious-political ends does not invalidate the experiences themselves, for functionality does not indicate functionalist origins. Given the abundant evidence for these types of experiences over hundreds of years and across cultures (Shushan, 2009, 2016a, 2016b), it is clearly a case of a particular experience type being interpreted in light of a particular situation and adapted and utilized for cultural/political 
needs and empowerment. It is worth emphasizing that at least one movement, that of the Wet'suwet'en prophet Bini, was alleged to have come about prior to any existential threat from Europeans (Lanoue, 1993, pp. 7, 19). Nor are these religions entirely defined by or limited to their historical contexts, for some are still extant today, including the Longhouse Religion and the Indian Shaker Church.

The importance of the experiential dimension is further attested by the fact that the movements were maintained and periodically revalidated by individuals having similar experiences: "From time to time, men 'died' and returned to life with renewed assurances of the truth of the doctrine" (Spier, 1935, p. 5). Over the course of four years, Mooney (1896, p. 924) found that even while the "original religious excitement" was waning, participation in the dances and other practices was on the rise. Indeed, these movements can be seen as democratizations of shamanism - the shamanization of the entire people in order to increase spiritual and political power. The process of the transmission and evolution of the newfound religious "knowledge" lay (a) in the telling and retelling of the narratives, resulting in greater elaboration and gradual mythologization; (b) in attempts by adherents to undergo similar experiences; and (c) in further spontaneous NDEs that served to revalidate earlier NDEs as well as shamanic, Ghost Dance, and Dreamer experiences while also authenticating ancient Orpheus myths and afterlife beliefs per se.

\section{References}

Andersson, R.-H. (2008). The Lakota Ghost Dance of 1890. Lincoln, NE: University of Nebraska Press.

Bancroft, H. H. (1875). The native races of the Pacific states of North America, Vol. III: Myths and languages. New York, NY: Appleton.

Barbeau, M. (1923). Indian days in the Canadian Rockies. Toronto, Canada: Macmillan.

Blair, E. H. (1911). Indian tribes of the Upper Mississippi Valley and region of the Great Lakes (2 vols.). Cleveland, $\mathrm{OH}$ : Clark.

Boas, F. (1896). The growth of Indian mythologies: A study based upon the growth of the mythologies of the north Pacific coast. Journal of American Folklore, 9(32), 1-11.

Cline, W. (1930). Religion and world view. In L. Spier (Ed.), The Sinkaietk or Southern Okanagon of Washington (pp. 131-182). Menahsa, WI: Banta.

Courlander, H. (1971). The Fourth World of the Hopis. New York, NY: Crown.

DeMallie, R. (Ed.). (1984). The sixth grandfather: Black Elk's teachings given to John G. Neihardt. Lincoln, NE: University of Nebraska.

de Quen, F. J. (1897). Relation de ce qui s'est passé en la Nouvelle France [Re- 
lation of what occurred in New France]. In R. B. Thwaities (Ed.), Travels and explorations of the Jesuit missionaries in New France (Vol. XLIII). Cleveland, $\mathrm{OH}$ : Burrows Brothers. (original work published 1657)

Du Bois, C. (1939). The 1870 Ghost Dance. Anthropological Records, 3(1). Berkeley, CA: University of California.

Gayton, A. H. (1935). The Orpheus myth in North America. Journal of American Folklore, 48 (189), 263-293.

Hallowell, A. I. (1940). Spirits of the dead in Salteaux life and thought. Journal of the Royal Anthropological Institute, 70, 29-51.

Hultkrantz, A. (1953). Conceptions of the soul among North American Indians. Stockholm, Sweden: Ethnographical Museum of Sweden.

Hultkrantz, A. (1957). The North American Indian Orpheus tradition. Stockholm, Sweden: Statens Etnografiska.

Hultkrantz, A. (1979). Religions of the American Indians. Berkeley, CA: University of California Press. (original work published 1967)

Hultkrantz, A. (1980). The problem of Christian influence on Northern Algonkian eschatology. Studies in Religion/Sciences Religieuses, 9(2), 161-183.

Hultkrantz, A. (1992). Shamanic healing and ritual drama, health and medicine in native North American religious traditions. New York, NY: Crossroads.

Huntington, D. B. (1919). Ute dialect, traditions and legends. In P. Gottfredson (Ed.), History of Indian depredations in Utah. Salt Lake City, UT: Skelton.

Jakobsen, M.D. (1999) Shamanism: Traditional and contemporary approaches to the mastery of spirits and healing. New York, NY: Berghan.

Jenness, D. (1938). The Sarcee Indians of Alberta. Bulletin 90, Anthropological Series 23. Ottawa, Canada: Department of Mines and Resources.

Kehoe, A. B. (2000). Shamans and religion: An anthropological exploration in critical thinking. Long Grove, IL: Waveland.

Kenton, E. (1927). The Indians of North America. New York, NY: Harcourt Brace.

Knapp, F. D., \& Childe, R. L. (1896). The Thlinkets of Southeastern Alaska. Chicago, IL: Stone and Kimball.

Kroeber, A. L. (1904). A ghost dance in California. Journal of American Folklore, 17(64), 32-35.

Lanoue, G. (1993). Orpheus in the netherworld in the Plateau of western North America: The voyage of Peni. In A. Masaracchia (Ed.), Orfeo e l' Orfismo. Atti del Seminario Nazionale (Roma-Perugia 1985-1991) [Orpheus and Orphism. Proceedings of the National Seminar (Rome-Perugia 1985-1991)], (pp. 447485). Rome, Italy: Gruppo Editoriale Internazionale.

Le Jeune, P. (1898). Relation de ce qui s'est passé en la Nouvelle France [Relation of what occurred in New France]. In R. B. Thwaities (Ed.), Travels and explorations of the Jesuit missionaries in New France (Vol. XVIII). Cleveland, $\mathrm{OH}$ : Burrows Brothers. (original work published 1640)

le Mercier, F. J. (1897). Relation de ce qui s'est passé en la Nouvelle France [Relation of what occurred in New France]. In R. B. Thwaities (Ed.), Travels and explorations of the Jesuit missionaries in New France (Vol. XV). Cleveland, $\mathrm{OH}$ : Burrows Brothers. (original work published 1638)

Loskiel, G. H. (1794). History of the mission of the United Brethren among the Indians of North America. London, UK: Brethren's Society. (original work published 1789) 
Lowie, R. H. (1909). The Northern Shoshone. Anthropological Papers, II(II). New York, NY: American Museum of Natural History.

McClenon, J. (2002). Wondrous healing: Shamanism, human evolution, and the origin of religion. DeKalb, IL: Northern Illinois University.

McClenon, J. (2006). The ritual healing theory: Therapeutic suggestion and the origin of religion. In P. McNamara (Ed.), Where God and science meet (Vol. 1, pp. 136-158). Westport, CT: Praeger.

Miller, J. (1988). Shamanic odyssey: The Lushootseed Salish journey to the land of the dead. Anthropological Papers. Ramona, CA: Ballena Press.

Mills, A., \& Slobodin, R. (Eds.). (1994). Amerindian rebirth: Reincarnation belief among North American Indians and Inuit. Toronto, Canada: University of Toronto Press.

Mooney, J. (1896). The Ghost-dance religion and the Sioux outbreak of 1890. Washington, DC: Government Printing Office.

Parker, A. C. (1913). The code of Handsome Lake, the Seneca prophet. Albany, NY: University of the State of New York.

Parkman, F. (1870). The conspiracy of Pontiac and the Indian War after the conquest of Canada. Boston, MA: Little Brown.

Ragueneau, P. (1897). Relation de ce qui s'est passé en la Nouvelle France [Relation of what occurred in New France]. In R. B. Thwaities (Ed.), Travels and explorations of the Jesuit missionaries in New France (Vol. XXX). Cleveland, $\mathrm{OH}$ : Burrows Brothers. (original work published 1646)

Rasmussen, K. (1932). Intellectual culture of the Copper Eskimos. Copenhagen, Denmark: Boghandel \& Forlag.

Ray, V. F. (1936). The Kolaskin cult: A prophet movement of 1870 in northeastern Washington. American Anthropologist, 38(1), 67-75.

Ruby, R. H., \& Brown, J. A. (1989). Dreamer prophets of the Columbia plateau: Smohalla and Skolaskin. Norman, OK: University of Oklahoma.

Ruby, R. H., \& Brown, J. A. (1996). John Slocum and the Indian Shaker Church. Norman, OK: University of Oklahoma.

Shushan, G. (2009). Conceptions of the afterlife in early civilizations: Universalism, constructivism, and near-death experience. New York, NY: Bloomsbury Continuum.

Shushan, G. (2016a). Cultural-linguistic constructivism and the challenge of near-death and out-of-body experience. In B. Schmidt (Ed.), The study of religious experience: Approaches and methodologies. London, UK: Equinox.

Shushan, G. (2016b). Near-death experience, shamanism, and afterlife beliefs in indigenous religions: A theoretically eclectic ethnohistorical approach. Manuscript in preparation.

Smoak, G. E. (2006). Ghost dances and identity: Prophetic religion and American Indian ethnogenesis in the nineteenth century. Berkeley, CA: University of California Press.

Spier, L. (1935). The Prophet Dance of the Northwest and its derivatives. Menasha, WI: Banta.

Swan, J. G. (1869). The Indians of Cape Flattery. Philadelphia, PA: Smithsonian Institution.

Talayesva, D. (1942) Sun Chief: The autobiography of a Hopi Indian. New Haven, CT: Yale University Press. 
Thompson, S. (1946). The folktale. New York, NY: Holt, Rinehart and Winston. Titiev, M. (1972). The Hopi Indians of Old Oraibi: Change and continuity. Ann Arbor, MI: University of Michigan Press.

Tylor, E. B. (1920 rpt.). Primitive culture (Vol. 2). London, UK: Murray. (original work published 1871)

Wade, J. (2003) In a sacred manner we died: Native American near-death experiences. Journal of Near-Death Studies, 22(2), 83-115. 